Meta

Journal des traducteurs

Translators' Journal

\title{
Error Analysis in Translation: A Preliminary Report
}

\section{H. Vivanco, J. Carlos Palazuelos, Patricia Hörmann, C. Garbarini et M. Blatrach}

Volume 35, numéro 3, septembre 1990

La traduction dans le monde hispanolusophone

URI : https://id.erudit.org/iderudit/002207ar

DOI : https://doi.org/10.7202/002207ar

Aller au sommaire du numéro

Éditeur(s)

Les Presses de l'Université de Montréal

ISSN

0026-0452 (imprimé)

1492-1421 (numérique)

Découvrir la revue

Citer cet article

Vivanco, H., Carlos Palazuelos, J., Hörmann, P., Garbarini, C. \& Blatrach, M.

(1990). Error Analysis in Translation: A Preliminary Report. Meta, 35(3),

538-542. https://doi.org/10.7202/002207ar d'utilisation que vous pouvez consulter en ligne. 


\title{
ERROR ANALYSIS IN TRANSLATION: A PRELIMINARY REPORT
}

\author{
H. Vivanco, J.C. Palazuelos, P. Hörmann, \\ C. Garbarini, M. Blajtrach, \\ Pontificia Universidad Católica de Chile, Santiago, Chile
}

The Catholic University of Chile created the Translation Program in 1971. It is a 5year program which provides general training in translation and offers two language combinations: English-French into Spanish and English-German into Spanish. During the 10 th and last term, students are required to do a translation practice outside the University ( 320 hours $=8$ hours per day during 2 months) and to prepare a small guided research paper. Students are also required to pass a final exam which consists of translating two texts (according to the language combination chosen) of approximately 300-350 words each and of defending their translation orally.

In 1987, a group of teachers including three translators and two linguists received funds from the Research Division ${ }^{*}$ of the Pontificia Universidad Católica de Chile to carry on a one-year project on error analysis of English into Spanish translations.

The project was originated after systematically observing that in the translation courses the nature of the errors made by the students varied widely. We believe that a clear distinction of the nature and characteristics of these errors could be of help to modify and restate, if necessary, the curricula of our Translation Program so as to minimize the occurrence of errors and to gain insight into the process of translation teaching.

This paper is a preliminary report of the studies, analyses and discussions carried out by the group in a six-month period. The corpus of our study includes translations from English into Spanish, that is, from a foreign language into the translator's native tongue, made by students from the first and last courses. Our research focuses on the definition of the concept of translation error. We will attempt a classification of errors after analyzing a sample of approximately 160 translations made by 20 students from the first and last courses of the program. The texts are varied: scientific, literary, political and technical.

The group contemplated the possibility of using the error analysis technique and of applying its theoretical principles that, although originally used to study the linguistic deviations generated by learners of an $\mathrm{L}_{2}$, seems to have applications in the field of translation errors.

This technique classifies errors according to the kind of deviation (morphosyntactic, lexical, phonological, on the one hand, of omission, addition, selection or misordering, on the other) and the mechanisms or strategies that generate them (transfer, overgeneralization, etc.). One of our objectives is to propose an ad-hoc taxonomy since we do not know of any classification specifically referring to translation errors, nor of a bibliography that provides theoretical foundations for the analysis of translation errors. Nevertheless, there are some models as the one proposed by P. Corder, which we will complement with the theoretical considerations made by E. Coseriu in his article "Lo acertado y lo erróneo en la teoría de la traducción", in El hombre y su lenguaje, 1985.

Our School of Translation postulates, believes and practices the principle that translators should translate into their mother or native tongue. It is often quoted that the

Meta, XXXV, 3, 1990 
language into which a text is translated is usually the native or a near-native language and that therefore, this is the area where problems are least expected. Notwithstanding, the scope and extent of the translation errors of students translating into their mother tongue is quite significant.

Studies done on a world-wide basis indicate that correct or proper expression (reflecting communicative competence) in one's mother tongue is a critical aspect of secondary and university education. Students do not always think logically and thus when writing they are unable to organize their thoughts in a rational way. This is an issue of major importance at present but one which we cannot obviously cover and do not intend to in this paper. We have only mentioned the point because "correct" written expression in one's native language is a "must" or a skill which eventually all translators should acquire.

Furthermore, studies conducted by Frank G. Königs at the University of Bochum, West Germany and by the National Resource Center for Translation and Interpretation, U.S.A., claim that even if an argument or an idea is clearly stated and many translators understand it, these same individuals many times cannot render a truly idiomatic text in their mother tongue. The texts are well written, paint a precise picture, yet the students have difficulty finding the most accurate structures.

What has come to be known as "error analysis" has generally been related to the investigation of the performance of second language learners. We are inclined to believe that this approach is not fully applicable when referring to translation errors. Nevertheless, we might say both share an identical ultimate object: explanation. The last stage in error analysis should always have a psycholinguistic basis, inasmuch as it attempts to account for how and why the errors have been made. We think, and we are sure many will agree, that there could be no reason to engage in error analysis unless we had in mind at least two aims: a linguistic and psycholinguistic one. Our aim is undoubtedly manifold or multiple. Consequently, we would expect our research project to provide relevant information in different areas:

- Contrastive analysis

- Types of errors

- Causes of errors and

- Translation teaching

According to modern linguists, errors have come to be regarded as evidence of the learner's strategies and the route he follows when building up his competence in the target language. This is the standpoint of Corder, among others, who states:

A learner's errors [...] are significant in three different ways. First to the teacher in that they tell him, if he undertakes a systematic analysis, how far towards the goal the learner has progressed and, consequently, what remains for him to learn. Second they provide to the researcher evidence of how language is learned or acquired, what strategies or procedures the learner is employing in his discovery of the language. Thirdly (and in a sense this is their most important aspect) they are indispensable to the learner himself because we can regard the making of errors as a device the learner uses in order to learn (Corder, 1967:167).

If translators want to theorize on the process behind error-making, on the psycholinguistic aspect of translation, we should then discuss the above stated point of view. Everything stated by Corder is certainly true when speaking of second language acquisition (and we as translators are in no position to argue his statement). Things change when we speak of error analysis in translation. First, errors are no doubt helpful to us as teachers of translation because they tell us what the problems are and how students are moving towards the goals we have in mind. Second, they might provide relevant data, if analysed systematically, on the causes of the errors. In what second language acquisition differs 
from translation, in relation to error analysis theories, is that in the case of translation, errors are not indispensable to the learner (or translator apprentice in our case) because they are not a device the "learner" or "translator" uses to learn. Rather, they are clear indications of several problems:

- interference of the source language in the target language,

- lack of comprehension of the source language,

a inadequate communicative competence or performance in the translator's mother tongue (considering the different components of communicative competence [CANALE 1983]),

- lack of extralinguistic background.

As already mentioned, we have based the present study on the linguistic theory of Eugenio Coseriu who considers translation should be a part of text linguistics.

The concept of error we have used is taken from the Diccionario de la Real Academia Española and coincides with the definition provided by Webster's New World Dictionary, 1972, which states that an error is "a departure from the accepted [...] code; transgression". A fault is "failure to have or do what is required". Errors can be detected either when speaking, writing or, in our case, when translating, at any of the following three levels: coherence of thought; correction or conformity to linguistic norms and adequacy of the text to the type of public or reader to whom the text is originally intended.

According to the above mentioned definitions an error or fault is meaningful when an "obligation" is transgressed, in other words when "a requirement is not met". What, then, are the "obligations or requirements" implicit in a translation which will allow an identification of errors?

Translation implies two types of "knowledge":

- one refers to knowing how to interpret the designation and the meaning of a text in a given source language.

- the other refers to knowing how to "re-produce" (to render) the designation and the meaning of a text in a given target language.

Since when speaking of translation we are talking of understanding, interpretation, and re-production of texts (rendering into a target language), we must take into account the idiomatic knowledge or level of our sampled students. By idiomatic knowledge we mean "speaking according to the linguistic tradition of a community". This because one of the variables that participate in favour or against reading comprehension and in favour or against the production of written texts is the speaker's linguistic competence (in $\mathrm{L}_{1}$ or $\mathrm{L}_{2}$ ).

When analyzing translations we could have the following relations:

a. Correct interpretation and reproduction

b. Correct interpretation and incorrect reproduction

c. Incorrect interpretation and reproduction

d. Incorrect interpretation and correct reproduction

These relations should be understood as follows:

a. The translator has correctly interpreted the textual content of the source text and has correctly reproduced (translated) this textual content into the target language. What we obtain here is a correct/adequate translation, that is, a translation without errors.

b. Correct interpretation of the textual content in the foreign language and incorrect reproduction (translation) of the same content in the target language. This means that the product, i.e., the translation, has errors due to an inadequate communicative competence in the target language on the part of the translator.

c. Incorrect interpretation and incorrect reproduction (translation) of the textual content. In this case, the translator has produced a translation which presents errors at two levels; 
comprehension of source language and rendering into the target language in conformity with linguistic norms.

d. Incorrect interpretation of the textual content and correct reproduction (translation) of the interpretation of said content. The result in this case is a translation which presents errors due to problems of comprehension of the foreign language. The translation reads smoothly, is adequate according to the linguistic norms of the target language. Unless the source text and the target text are compared nobody will know the translation is unfaithful to the original message.

Accordingly:

a) implies a "correct" or "good" translation

b) and d) could be evaluated as incorrect translations because of errors at the level of rendering into a target language or at the level of decoding the foreign language

c) will always mean a "very bad" translation because of errors made at both levels (foreign language or source language and mother tongue or target language).

In brief, up to now our analysis has allowed us to reach certain conclusions, which at the same time open a way to methodological aspects.

A translation is subject to errors which could be of two types: translation errors and errors due to a lack of competence in the target language. But indeed, how can we know or be sure if the cause of the translation error is an incorrect interpretation, or an incorrect reproduction? Therefore, when analyzing translation errors, both the source and the target texts should be at hand. When speaking of "literal" (word by word) translation, how can we know if such a translation was caused by lack of understanding or simply because the translator was "careless"?

The findings of this research should lead to an error taxonomy which will allow us to study the linguistic and psychological mechanisms involved when re-creating in a natural tongue a message originally expressed in a different one. They could also be applied to improve the teaching methodology in the translation as well as in the foreign language undergraduate and graduate programs. In general, they will be useful to improve evaluation systems and particularly to unify evaluation criteria among the teaching staff of the Department of Translation. On a more specific basis, this research could serve to reinforce the teaching of $\mathrm{L}_{1}$ and $\mathrm{L}_{2}$ within a Translation Program and to systematize structural and lexical contents in practical courses of translation.

Finally, we hope that it will throw some light on several issues or at least pave the way to new research projects which will help consolidate the study of translation at a scientific level.

* The Research Division promotes and finances research projects presented by academic staff working at the Pontificia Universidad Católica de Chile. Each year, this division organizes a contest through which funds are awarded on a 1-2 or 3 year basis to projects that have been successfully evaluated by referees from national or foreign universities or scientific organizations. 


\section{BIBLIOGRAPHY}

CANALE, M. (1983): "From communicative competence to communicative language pedagogy", in Richards and Schmitt (eds) Language and Communication, Burnt Mill, Harlow, Longman.

COSERIU, E. (1985): "Lo erróneo y lo acertado acerca de la teoría de la traducción", en El hombre y su lenguage, Editorial Gredos.

CORDER, S. PIT. (1981): "Error analysis and interlanguage", Oxford University Press.

CORDER, S. PIT. (1967): "The significance of learner's errors", IRAL, p. 161-170.

FAERCH, C. and G. KASPER eds.(1983): Strutegies in Interlanguage communication, Longman.

KÖNIGS, F.G. (1987): "Was beim Übersetzen passiert. Theoretische Aspekte, empirische Befunde und praktische Konsequenzen" in Die Neueren Sprachen 2, pp. 162-185.

BUSKIRK, C. and D. BOWEN: "Final testing of translation students", National Resource Center for Translation and Interpretation, U.S.A.

NEHLS, D. (1979): Studies in Contrastive Linguistics and Error Analysis, The Theoretical Background, Heidelberg, Julius Groos.

REAL ACADEMIA ESPAÑOLA (R.A.E.) (1970): Diccionario de la Lengua Española, Editorial EspasaCalpe, Madrid.

RICHARDS, J. (1974): Error Analysis. Perspectives on Second Language Acquisition, Longman.

WEBSTER'S NEW WORLD DICTIONARY OF THE AMERICAN LANGUAGE (1972), Second College Edition, New York, The World Publishing Company. 